\title{
Introduction of the new geodetic datums and map projections in the Federation of Bosnia and Herzegovina
}

\author{
Slobodanka Ključanin \\ University of Bihać, Faculty of Technical Engineering, prof. Ph.D \\ slobodanka63@yahoo.com \\ Ervin Redžepagić \\ Federal administration for Geodetic and Property Affairs, B. Sc (Geodesy) \\ ervin.redzepagic@gmail.com
}

\begin{abstract}
The globalization of geospatial data and geodetic reference frames is important for the overall development of both national and global economies. In accordance with the needs for defining a general geodetic reference frame, the United Nations General Assembly adopted the resolution "Global Geodetic Reference Frame for Sustainable Development (GGRF)" in 2015. The European Union member states have addressed the issue by adopting joint directives, recommendations and other acts to adapt national laws. Bosnia and Herzegovina and its neighboring countries, non-EU member states, have enacted appropriate legislation and decisions to adapt to the globalization of spatial data and reference frames. Therefore, the Federal Administration for Geodetic and Property Affairs (FGU) has undertaken certain activities in order to establish a new geodetic reference frame through changes in legislation, renewal and establishment of new reference systems and measurements. The paper will discuss the existing geodetic reference frame and the activities of the FGU on the introduction of new geodetic datums and map projections in the Federation of Bosnia and Herzegovina (FBiH).
\end{abstract}

Key words: globalization, geospatial data, geodetic reference frames, geodetic datum of $\mathrm{FBiH}$

\section{Uvođenje novih geodetskih datuma i kartografske projekcije u Federaciji Bosne i Hercegovine}

Sažetak: Globalizacija geoprostornih podataka i referentnih geodetskih okvira je potreba za cjelokupni razvoj kako nacionalnih ekonomija tako i ekonomije na svjetskoj razini. Sukladno potrebama definiranja općeg geodetskog referentnog okvira, 2015. godine, Ujedinjene nacije na svojoj Generalnoj skupštini usvojile su rezoluciju „Globalni geodetski referentni okvir za održivi razvoj (Global Geodetic Reference Frame for Sustainable Development - GGRF)“. Članice Europske unije (EU) rješavaju taj problem donošenjem zajedničkih direktiva, preporuka i drugih akata, kako bi se prilagodili nacionalni zakoni država članica. Bosna i Hercegovina i njoj susjedne države, koje nisu članice EU donijele su odgovarajuće zakonske propise i odluke kako bi se prilagodile globalizaciji prostornih podataka i referentnih okvira. Stoga je i Federalna uprava za geodetske i imovinsko-pravne poslove (FGU) poduzela određene aktivnosti u cilju uspostavljanja novih geodetskih referentnih okvira kroz promjenu zakonske regulative, obnovu i uspostavu novih referentnih sustava i izvođenja mjerenja. U članku će biti riječi o postojećem geodetskom referentnom okviru i aktivnostima FGU na uvođenju novih geodetskih datuma i kartografske projekcije u Federaciji Bosne i Hercegovine.

Ključne riječi: globalizacija, geoprostorni podaci, geodetski referentni okviri, geodetski datum $\mathrm{FBiH}$

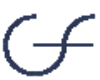


Ključanin, S., Redžepagić, E.

Introduction of the new geodetic datums and map projections in the Federation of Bosnia and Herzegovina

\section{INTRODUCTION}

Geodesy (geomatics) is defined as a profession that deals with modeling and implementation of spatial systems, methods of collecting spatial data, their analysis, visualization and interpretation (Bašić, 1999). In order to meet the requirements for globalization of geospatial data, it is necessary to define a new geodetic datum or geodetic reference system. Geodetic datum is a datum that describes the relation of origin and orientation of axes of a coordinate system related to the Earth. Defining the global datum requires at least eight parameters: three to define the origin of the coordinate system, three to define the orientation of the coordinate system and two to determine the dimensions of the geodetic ellipsoid. A local datum is usually defined by five parameters: the latitude and longitude of the fundamental point, the azimuth from the fundamental point to one side, and two parameters of the ellipsoid. The elements of deflection of the vertical at the fundamental point, or the condition that the minor axis of the ellipsoid is parallel to the Earth's rotation axis were additionally set (Frančula and Lapaine, 2008).

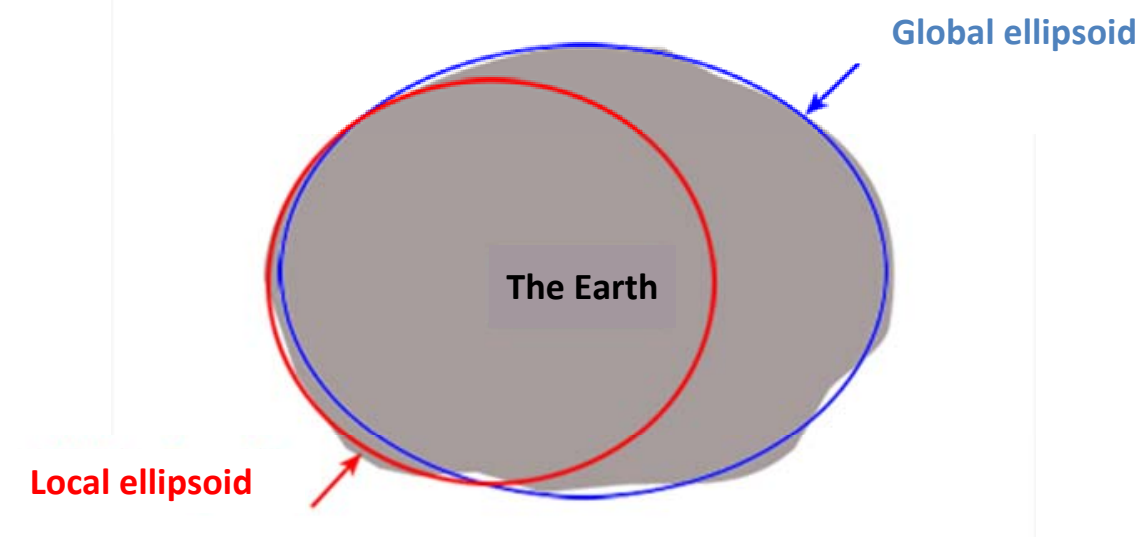

Figure 1. The difference between local and global datums. The ellipsoid for a global datum is sized and positioned to best represent the surface of the Earth on a global scale. Local datums have their own ellipsoids dimensioned and positioned to better fit a specific area of the Earth (geoid) (URL1).

Geodetic measurements performed on the Earth's surface must be reduced to the adopted mathematical surface, or the adopted rotational ellipsoid, which can be global or local. The local reference ellipsoid is adopted to best match the geoid ${ }^{1}$ in the area of local interest. This means that the difference between the geoid and the reference rotational ellipsoid can be ignored. This makes it possible to develop accurate maps of the Earth's surface. The global reference rotational ellipsoid, unlike the local ellipsoid, fits the geoid of the entire globe (see Figure 1).

\footnotetext{
${ }^{1}$ The geoid is an equipotential surface, i.e. an imaginary surface that includes all points in space at which the potential of a physical field is of equal value. Geoid is considered to be the best approximation of the Earth.
} 
Ključanin, S., Redžepagić, E.

Introduction of the new geodetic datums and map projections in the Federation of Bosnia and Herzegovina

\section{REFERENCE SYSTEMS OF THE FEDERATION OF BOSNIA AND HERZEGOVINA}

\subsection{Inherited reference systems}

Existing reference systems that are still in use are classified into: positional, vertical, gravimetric and astrogeodetic reference system.

\subsubsection{Positional reference system}

The foundation of today's positional geodetic datum in the Federation of $\mathrm{BiH}$ was determined by the works of the Military Geographical Institute (MGI) of the Austro-Hungarian Monarchy. The fundamental point of the system is Hermannskogel, whose position $\varphi_{0}=48^{\circ} 16^{\prime} 15.29^{\prime \prime}$, $\lambda_{0}=33^{\circ} 57^{\prime} 41.06^{\prime \prime}$ (prime meridian Ferro) is determined by astronomical measurements, just as the orientation of the network, which is defined by astronomical azimuth $A=107^{\circ} 31^{\prime} 41.70 "$ to the adjacent point of the Hundesheimer Berg triangulation network. The Bessel ellipsoid was chosen as the mathematical model for the Earth (MGI, 1901; Bašić, 1999). Based on the existing Austro-Hungarian network, the Military Geographical Institute from Belgrade (VGI) defined the first-order triangulation network of the former Yugoslavia between the two world wars, and after the Second World War re-surveyed the entire first order network, but the results of these measurements were never actually put into civilian use. Many of these triangulation stations were permanently marked again over time, so their position coordinates and elevations are changed. It should be mentioned that despite this, the heights were literally taken over from the Austro-Hungarian triangulation (data by meter). It is established that there are three main shortcomings of the existing triangulation network. Point heights are determined with a significantly lower quality than position coordinates, which is a major problem when transforming new (GPS) measurements into an existing local datum. The existing network is poorly documented, and permanent marking of survey points is generally unsuitable for practical GPS measurements, because they are most often located on high and inaccessible hills (Bašić 1999; Peterca and Čolović 1987, Delčev et al. 2014, Šugar et al. 2015, Zimić and Đonlagić 2017, Mugnier 2012).

\subsubsection{Vertical reference system}

The origin of the vertical system for the Federation of Bosnia and Herzegovina is defined by the mean sea level, based on tide gauge observations at the Sartorio pier in Trieste in 1875. The first basic works of this type were performed by MGI between 1878 and 1905, then the first High Accuracy Leveling (NVT1) was made in the period between 1946 and 1957, and the second NVT (NVT2) between 1968 and 1972. NVT2 has never been officially adopted and put into official use, so NVT1 elevations are still in use. In addition to the age of this data and the marginal location of the point of origin Trieste, a big problem comes from the fact that heights of the benchmarks include the error of the mean sea level of the tide gauge in Trieste (Bašić, 1999). In Europe, three different types of heights are used in practice: normal, orthometric and normal orthometric heights ${ }^{2}$. Orthometric heights are used in Belgium,

\footnotetext{
${ }^{2}$ Orthometric, dynamic and normal heights are considered to be true heights, and normal orthometric heights are considered to be approximately defined (Idhe, 2006; Bilajbegović and Mulić, 2013). The normal orthometric system of heights does not allow mathematical determination of the reference surface, but it is approximated on
} 
Ključanin, S., Redžepagić, E.

Introduction of the new geodetic datums and map projections in the Federation of Bosnia and Herzegovina

Denmark, Italy, etc., and normal ones in France, Germany, Scandinavian countries, etc. Normal orthometric heights are used in the countries that emerged from the breakup of the former SFRY, namely Croatia, Slovenia, Bosnia and Herzegovina, Montenegro and Macedonia, as well as in Albania, while in Serbia normal heights are used since 2012 (OG RS 2012, Grgić et al. 2015).

\subsubsection{Gravimetric measurements}

In the former Yugoslavia, gravimetric measurements were within the competence of the Military Geographical Institute. The data of these measurements were considered a military secret, so information on the method of measurement, calibration of gravimeters and calculation of the normal gravity acceleration value is unknown. Also, there are no reliable data on most gravimetric points. In addition to absolute measurements, a first-order gravimetric network (14 points), a basic gravimetric network and a second-order gravimetric network were established between 1952 and 1974. In addition to these points, maps of Bouguer anomalies, as well as free air anomalies, in the Potsdam gravity acceleration system, were developed. The former state was also connected to the IGSN71 gravimetric reference system with three points (Bašić and Bačić 1999, Bašić, 1999, Zimić and Đonlagić 2017).

\subsubsection{Astrogeodetic network}

In parallel with the development of trigonometric networks, astronomical determinations of the coordinates of the points of trigonometric networks, or determinations of astrogeodetic deviations of verticals, were performed. Lack of financial resources and expensive works dependent on the technology of that time resulted in a small number of unevenly distributed points at which the measurements were performed, which was insufficient for determining the astrogeodetic network of the former Yugoslavia or accurately determine geoids (Zimić and Đonlagić 2017).

\section{NEW REFERENCE SYSTEMS IN THE FEDERATION OF BOSNIA AND HERZEGOVINA}

Introduction of new geodetic reference systems in the Federation of Bosnia and Herzegovina has become a necessity in order to meet the requirements for globalization of geospatial data, but also to bring the existing geodetic reference systems into compliance with European recommendations and trends. For example, insufficient accuracy and significant errors in existing reference systems makes them inadequate for the use of new measurement technology and for modern user requirements, as well as for creating preconditions for the development of the information society. According to Zimić and Đonlagić (2017), most European countries have prescribed four geodetic reference systems:

- Spatial reference system - 3D

- Horizontal reference system - 2D

- Vertical (height) reference system - 1D

the basis of a large number of points with known ellipsoidal and normal orthometric heights (Official Gazette of the Federation of $\mathrm{BiH}$, No. 15/19). 
Ključanin, S., Redžepagić, E.

Introduction of the new geodetic datums and map projections in the Federation of Bosnia and Herzegovina

- Gravimetric reference system.

The Rulebook on basic geodetic works (Official Gazette of the Federation of $\mathrm{BiH}$, No. 15/19) aims to define, establish and maintain a geodetic reference system and the appropriate reference framework of the Federation of Bosnia and Herzegovina, which consists of:

1. spatial reference system;

2. reference system in the projection plane;

3. vertical reference system;

4. gravimetric reference system;

5. astronomical-geodetic reference system; and

6. magnetic reference system.

\subsection{Spatial reference system of the Federation of $\mathrm{BiH}$}

Article 8 of the Rulebook on basic geodetic works (hereinafter: the Rulebook) provides a definition of the spatial reference system and reads:

"The spatial reference system of the Federation of Bosnia and Herzegovina is a geocentric terrestrial reference system which, by definition of coordinate origin, by coordinate axis orientation, scale, unit of length and temporal evolution, coincides with the International Terrestrial Reference System - ITRS for epoch 1989.0 - ITRS 89 and is called the European Terrestrial Reference System - ETRS 89, implemented by the European Terrestrial Reference Frame - ETRF 89. ETRS 89 is a regional terrestrial reference system of Europe, fixed to the European continental mass with which it participates in lithosphere tectonics, materialized with ETRF89 consisting of permanent GNSS stations and operational centers (local and regional) for control, processing and dissemination of data."

However, the work on establishing and connecting the spatial GPS network with the region and Europe was in progress even before the adoption of the Rulebook. The first GPS measurements in BiH were performed in 1997 (four points), and in 1998 a EUREF'98 GPS campaign was conducted in Albania, Bosnia and Herzegovina and Yugoslavia, which included 13 points in the territory of $\mathrm{BiH}$ (Altiner et al. 1999). In 2000, the passive reference network BIHREF was created, which was the first densification of the network in both entities (Federation of $\mathrm{BiH}$ and Republic of Srpska). FBiHPOS is the positioning system of the Federation of Bosnia and Herzegovina, the control center of which is in Sarajevo. There are a total of 20 permanent GNSS stations in the territory of $\mathrm{FBiH}$. In order to optimize the geometric shape, the permanent network also included in its system 12 stations from the Republic of Srpska and two from the neighboring Republic of Croatia. Positioning is performed in real time with an accuracy of 1 to $2 \mathrm{~cm}$ (URL2).

\subsubsection{Transformation parameters}

The international standard IS019111 (ISO19111: Geographic information - Spatial referencing by coordinates) makes a distinction between "coordinate conversion" and "coordinate transformation". Coordinate conversion means the conversion of coordinates from one coordinate system to another, where both systems have the same geodetic datum. Coordinate transformation means the transformation of coordinates from one coordinate system to another, where the coordinate systems are in different geodetic datums (URL3). 
Ključanin, S., Redžepagić, E.

Introduction of the new geodetic datums and map projections in the Federation of Bosnia and Herzegovina

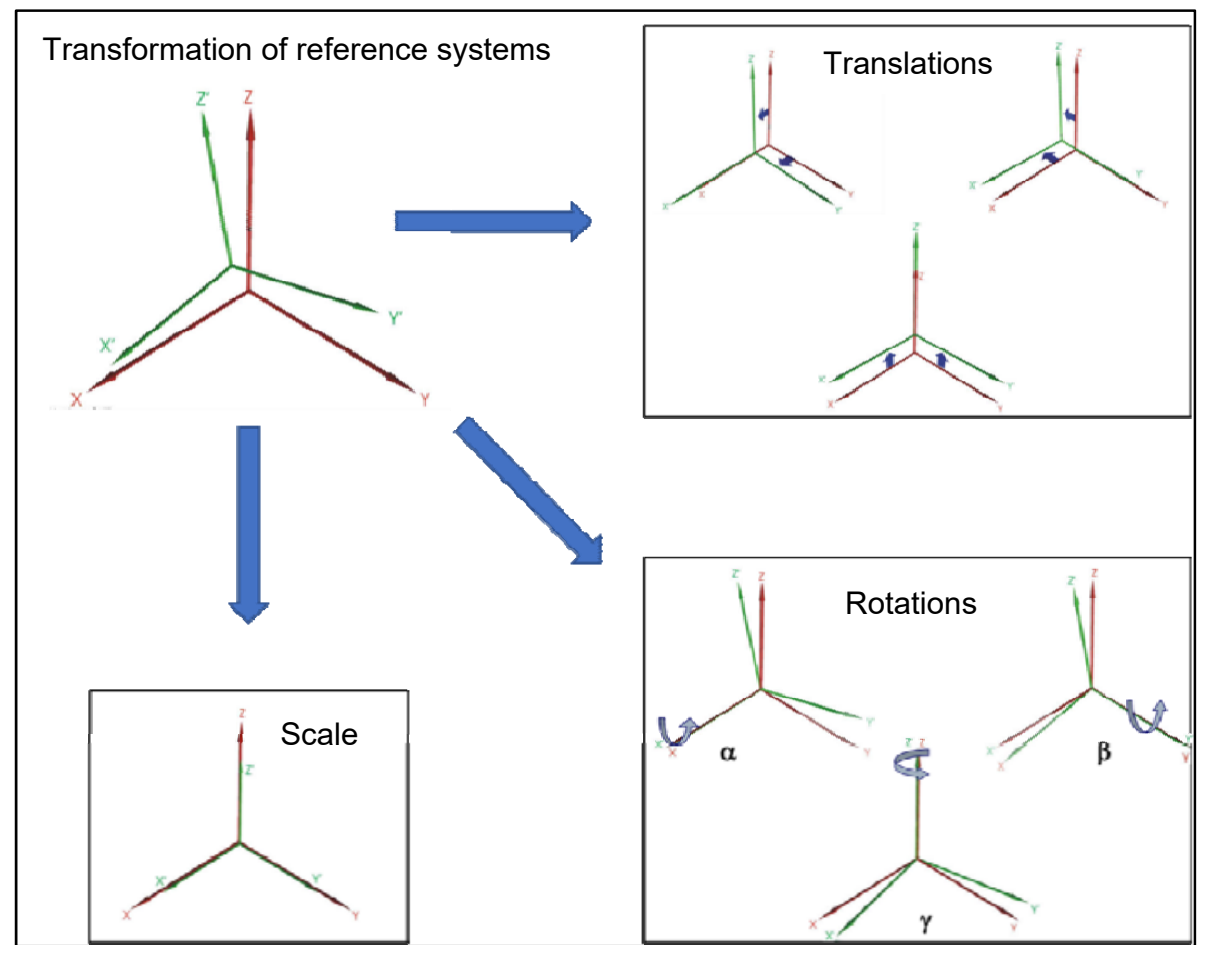

Figure 2. Seven parameters of transformation of two coordinate systems of different datums (URL3)

The set of parameters defining the datum transformation are called transformation parameters. The transformation requires seven parameters to be known (three translations, three rotations and one scale parameter, see Figure 2), so it is called the seven-parameter datum transformation or Helmert transformation (Vušović et al. 2012).

In Bosnia and Herzegovina, the parameters of transformation between the current state coordinate system and the spatial reference system ETRS89 were calculated based on GNSS measurements at over 2500 points (Zimić and Đonlagić 2017).

\subsection{Reference system in the projection plane}

The rulebook has denoted this reference system as BH_ETRS89/TM. BH_ETRS89/TM is defined by rectangular coordinates in the plane of the conformal Transverse Mercator projection (TM) of the GRS80 ellipsoid. The N axis of the coordinate system, is oriented to the north and coincides with the meridian of longitude $18^{\circ}$ east of the prime meridian. The scale on the central meridian is $\mathrm{m}_{0}=0.9999$. The second axis, perpendicular to $\mathrm{N}$, is marked as $\mathrm{E}$, and its positive value increases to the east. The coordinates of the origin of this reference system are: $\mathrm{N}=0 \mathrm{~m}, \mathrm{E}=500000 \mathrm{~m}$ or $(\mathrm{N}, \mathrm{E})=(0,500000)$.

As the process of transition to the new reference system is a process that takes years, in the meantime the inherited coordinate reference system will be used in the plane of Gauss-Krüger projection (the so-called National Coordinate System - DKS) of the Bessel 1841 ellipsoid with three projection zones with initial meridians $15^{\circ}$ (Zone 5), $18^{\circ}$ (Zone 6) and $21^{\circ}$ (Zone 7) east of the prime meridian. The coordinates of the origins of these projection zones are $(y, x)=(5,6,7,00000,0)$. The correlation between the new 
Ključanin, S., Redžepagić, E.

Introduction of the new geodetic datums and map projections in the Federation of Bosnia and Herzegovina

BH_ETRS89/TM and the existing DKS system is established by applying the appropriate datum transformations.

\subsection{Vertical reference system}

BH_VRS2020 is the designation of the new vertical reference system of the Federation of $\mathrm{BiH}^{-}$. This system makes it possible to use geopotential numbers and normal and orthometric heights related to tide gauges in the Adriatic Sea for the epoch of 1971.5 and the mean height of the Amsterdam benchmark NAP and to establish relationships between ellipsoid (ellipsoid GRS80) and other heights.

Like with the reference system in the projection plane, the Rulebook prescribes that the inherited vertical systems, BH_VRS1875 and BH_VRS1971,5, are to be used until superseded by the new vertical system of the Federation of $\mathrm{BiH}$. The vertical system $\mathrm{BH}$ _VRS1875 is the result of the first high-accuracy leveling (NVT1) based on AustroHungarian precision leveling, with normal orthometric heights and a reference surface defined by the mean level of the Adriatic Sea based on one-year tide gauge measurements at the Sartorio pier in Trieste in 1875. The vertical system BH_VRS1971.5 is the result of the second high-accuracy leveling (NVT2), the reference surface of which was determined by the mean sea level in a period of 18.6 years by tide gauges in Dubrovnik, Split, Bakar, Rovinj and Koper for the epoch of 1971.5. Four-time leveling measurements of the leveling lines Split - Dubrovnik - Maglaj established a normal benchmark in Maglaj in the system of normal orthometric heights.

\subsection{Gravimetric reference system}

According to the Rulebook, the International Gravity Standardization Network 1971 with the designation IGSN 71 is adopted as the gravimetric reference system of the Federation of $\mathrm{BiH}^{3}$. The gravimetric reference frame of the Federation of Bosnia and Herzegovina consists of the networks of the zeroth, first (basic gravimetric network) and second order (secondary gravimetric network). The value of gravity acceleration is determined by the method of absolute gravimetry at four points for the zero-order network, and for the basic gravimetric network by the method of relative gravimetry at 30 points at an average distance of $30 \mathrm{~km}$. The secondary gravimetric network measures the gravity acceleration values using the method of relative gravimetry at points at an average distance of less than $15 \mathrm{~km}$.

\subsection{Astronomical-geodetic reference system}

The astronomical-geodetic reference framework of the Federation of Bosnia and Herzegovina consists of all points of the spatial reference framework at which astronomical measurements were performed for the purpose of determining astronomical latitude, astronomical longitude and astronomical azimuth. The ICRS (International Celestial Reference System) - an astronomical reference system adopted by the IAG (International Association of Geodesy) - is applied in the Federation of $\mathrm{BiH}$.

\subsection{Magnetic reference system}

\footnotetext{
${ }^{3}$ The values of gravity acceleration of the basic gravimetric network points are related to the time epoch 1971.0.
} 
Ključanin, S., Redžepagić, E.

Introduction of the new geodetic datums and map projections in the Federation of Bosnia and Herzegovina

According to the Rulebook for the establishment and maintenance of the magnetic reference system, the standards and recommendations of IAGA (International Association of Geomagnetism and Aeronomy) and MagNetE (Magnetic Network in Europe) are adopted. The geomagnetic network is primarily used to determine the geomagnetic declination and its annual change, and consists of:

1. geomagnetic repeat stations network (determination of annual change of geomagnetic declinations) and

2. basic geomagnetic network (established to determine the values of magnetic field elements: declination, inclination and intensity for different needs).

\section{IMPLEMENTATION OF WORKS ON THE ESTABLISHMENT OF NEW REFERENCE SYSTEMS}

\subsection{Establishment and renewal of the spatial reference system of the Federation of B\&H}

The spatial reference system is materialized by a spatial coordinate reference frame, or a set of materialized geodetic points with coordinates $\mathrm{X}, \mathrm{Y}, \mathrm{Z}$ or $\varphi, \lambda$ and $\mathrm{h}$ (Figure 3 ). The spatial reference frame hierarchically consists of: 1) zero-order reference frame, 2) first-order reference frame, 3) second-order reference frame, and 4) third-order reference frame.

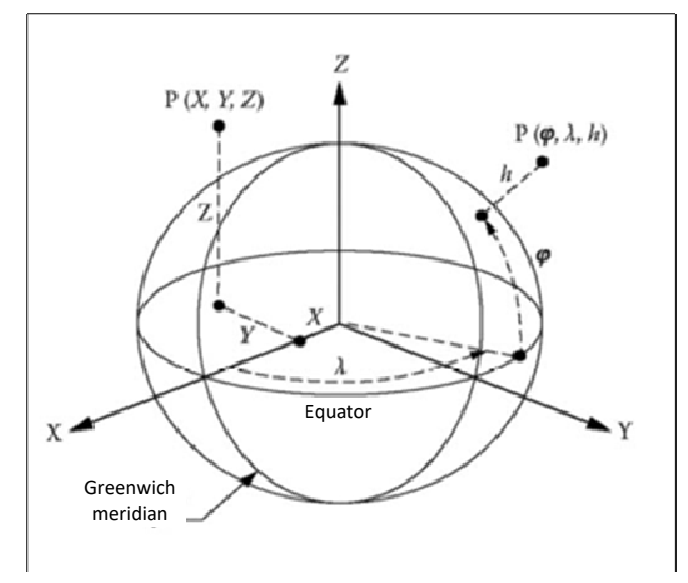

Figure 3. Geodetic coordinates in the spatial reference system (source: Rulebook on basic geodetic works)

\subsubsection{Zero-order reference frame}

The zero-order reference frame of the Federation of Bosnia and Herzegovina consists of the network of permanent GNSS stations "BiHPOS" and the existing triangulation points included in the single European network through the GPS campaign "EUREF 98". Since September 2011, Bosnia and Herzegovina is one of the countries using permanent GNSS station technology. The BiHPOS project was implemented by building two complementary satellite positioning networks: SRPOS (for the territory of the Republic of Srpska) and FBiHPOS (for the territory of the Federation of Bosnia and Herzegovina). 
Ključanin, S., Redžepagić, E.

Introduction of the new geodetic datums and map projections in the Federation of Bosnia and Herzegovina

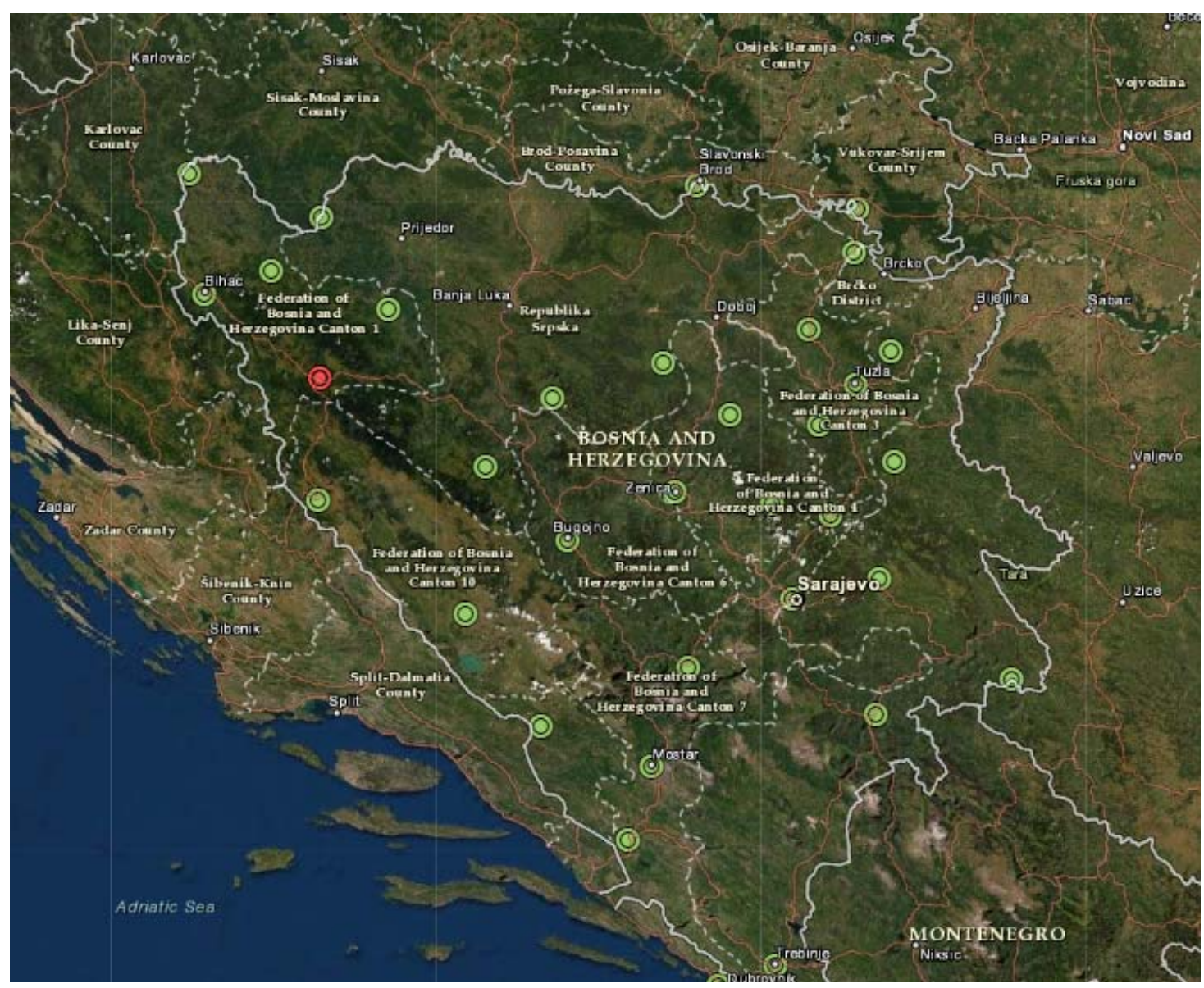

Figure 4. View of the distribution of FBiHPOS stations with 12 SRPOS stations and 2 CROPOS stations (URL4)

The BIHPOS network initially consisted of 34 GNSS stations, 17 of which were installed in the territory of the Federation of BiH with a control center in Sarajevo (FBIHPOS system), and the remaining 17 stations were installed in the Republic of Srpska with a control center in Banja Luka (SRPOS system). In the past 2-3 years, the FBIHPOS network has been expanded to 20 stations by installing new stations in Vareš and Bosanska Krupa and including the city's permanent network in Tuzla in the system. Services of the network of permanent stations can be used throughout Bosnia and Herzegovina because the BIHPOS systems (FBIHPOS and SRPOS) and CROPOS exchange measurement data in border areas. In this case, the FBIHPOS network consists of 34 GNSS stations (20 stations in the Federation of $\mathrm{BiH}, 12$ stations from SRPOS, 2 stations from CROPOS) and a control center in Sarajevo (Figure 4).

\subsubsection{First-order reference frame}

The first-order reference frame of the Federation of Bosnia and Herzegovina consists of the triangulation network points (14 points of the first order triangulation stations) at which measurements were performed and coordinates determined in the ETRS89 system during the GNSS campaign "BIHREF2000". 
Ključanin, S., Redžepagić, E.

Introduction of the new geodetic datums and map projections in the Federation of Bosnia and Herzegovina

\subsubsection{Second-order reference frame}

The second-order reference frame of the Federation of Bosnia and Herzegovina is developed by densifying higher-order reference frames, and it consists of spatial reference frame points permanently marked in the Federation of $\mathrm{BiH}$ at an average distance of 10-15 $\mathrm{km}$ (points are denoted by an alphanumeric code, e.g. FD147) and all fundamental benchmarks of the third high-accuracy leveling (NVT3) suitable for GNSS measurements (points are denoted by an alphanumeric code, e.g. FR01).

As part of the implementation of the project of the third high-accuracy leveling (NVT3), which began in mid-2019, static GNSS measurements were performed at points of the spatial reference network and at fundamental benchmarks. Of the planned 176 points of the spatial network, 174 were measured (2 were destroyed) and 13 fundamental benchmarks were measured. The method of determining the three-dimensional Cartesian position of points was rapid statics in accordance with the provisions of the Rulebook on the application of satellite measurements in geodesy ("Official Gazette of the Federation of BiH", No. 18/12).

After a priori assessment of the accuracy and analysis of the closure of the figures, a control free adjustment was performed, followed by a definitive indirect adjustment with constraint to zero-order points. All coordinates were calculated in the ETRS89 coordinate system, epoch 2011307 (epoch in which the FBIHPOS system was calculated). Standard deviations are also given (Table 1) by coordinate axes (Tabaković et al. 2020).

Table 1. Spatial reference network points with accuracy assessment (excerpt of the original table)

\begin{tabular}{|c|c|c|c|}
\hline NAME & $\begin{array}{c}s \mathrm{~s} \\
{[\mathrm{~m}]}\end{array}$ & $\begin{array}{c}\mathrm{sY} \\
{[\mathrm{m}]}\end{array}$ & $\begin{array}{c}\mathrm{sZ} \\
{[\mathrm{m}]}\end{array}$ \\
\hline FD1 & 0.015 & 0.006 & 0.015 \\
\hline FD10 & 0.003 & 0.002 & 0.003 \\
\hline FD100 & 0.009 & 0.006 & 0.008 \\
\hline FD101 & 0.011 & 0.007 & 0.011 \\
\hline FD102 & 0.011 & 0.004 & 0.011 \\
\hline FD103 & 0.014 & 0.005 & 0.014 \\
\hline FD104 & 0.007 & 0.003 & 0.007 \\
\hline FD105 & 0.005 & 0.003 & 0.005 \\
\hline
\end{tabular}

\begin{tabular}{|c|c|c|c|}
\hline NAME & $\begin{array}{c}\mathrm{sX} \\
{[\mathrm{m}]}\end{array}$ & $\begin{array}{c}\mathrm{sY} \\
{[\mathrm{m}]}\end{array}$ & $\begin{array}{c}\mathrm{sZ} \\
{[\mathrm{m}]}\end{array}$ \\
\hline FD146 & 0.002 & 0.001 & 0.002 \\
\hline FD147 & 0.018 & 0.006 & 0.018 \\
\hline FD148 & 0.016 & 0.006 & 0.016 \\
\hline FD149 & 0.006 & 0.003 & 0.006 \\
\hline FD15 & 0.003 & 0.002 & 0.003 \\
\hline FD150 & 0.003 & 0.003 & 0.003 \\
\hline FD151 & 0.017 & 0.006 & 0.017 \\
\hline FD152 & 0.018 & 0.005 & 0.020 \\
\hline
\end{tabular}

\begin{tabular}{|c|c|c|c|}
\hline NAME & $\begin{array}{c}\mathrm{sX} \\
{[\mathrm{m}]}\end{array}$ & $\begin{array}{c}\mathrm{sY} \\
{[\mathrm{m}]}\end{array}$ & $\begin{array}{c}\mathrm{sZ} \\
{[\mathrm{m}]}\end{array}$ \\
\hline FD4 & 0.019 & 0.007 & 0.019 \\
\hline FD40 & 0.015 & 0.005 & 0.015 \\
\hline FD41 & 0.019 & 0.007 & 0.018 \\
\hline FD42 & 0.008 & 0.003 & 0.008 \\
\hline FD43 & 0.012 & 0.004 & 0.011 \\
\hline FD44 & 0.006 & 0.003 & 0.005 \\
\hline FD45 & 0.004 & 0.002 & 0.003 \\
\hline FD46 & 0.005 & 0.003 & 0.005 \\
\hline
\end{tabular}

The ellipsoidal heights of points of the spatial reference network, as well as their standard deviations, were determined by adjustment. The average value of standard deviations is 1.4 $\mathrm{cm}$. As the points of the spatial network were observed in two sessions, a separate adjustment of the network for both sessions was performed for control. After adjustment, a comparison of ellipsoidal heights determined in the first and second sessions was performed for each point of the spatial network. The comparison established that the average height deviation between the two sessions was $1.3 \mathrm{~cm}$ (Tabaković et al. 2020).

\subsubsection{Third-order reference frame}

The third-order reference frame of the Federation of $\mathrm{BiH}$ is developed by densifying the higherorder reference frames, and consists of city GNSS networks, GNSS networks created during the survey of the Federation of $\mathrm{BiH}$ and all NVT3 benchmarks at which direct measurement with GNSS devices is possible. 
Ključanin, S., Redžepagić, E.

Introduction of the new geodetic datums and map projections in the Federation of Bosnia and Herzegovina

The development of city networks is implemented slowly, because priority is given to the establishment of the FBIHPOS system of permanent stations. FBIHPOS provides the service of sharing the positional parameters of grid transformation, which are sent to users via RTK corrections for the automatic coordinate system. Initially, this system consisted of approximately 1450 points (mostly third and fourth order triangulation stations) while now that number is almost 2500 points.

According to Bilajbegović and Odalović (2017), the coordinates of all NVT3 benchmarks should be determined due to the normal gravity acceleration in relation to the normal potential of the Geodetic Reference System 1980 (GRS80), discrete values of height anomalies or geoid undulations and assignment of coordinates to measured gravity acceleration values at benchmarks. In practice, measurements and calculations were performed on average for every fifth benchmark in the leveling line, while taking into account that two adjacent observed benchmarks are at a maximum distance of $5 \mathrm{~km}$. The measurements began in the middle of 2019 and end in December 2021. So far, the coordinates of 372 benchmarks are defined using the method of determining the three-dimensional Cartesian position of benchmarks by rapid statics.

After a priori assessment of the accuracy and analysis of the closure of the figures, a control free adjustment was performed, followed by a final indirect adjustment with constraint to VRS (Virtual Reference Stations created by the FBIHPOS system for arbitrary location) points. All coordinates were calculated in the ETRS89 coordinate system, epoch 2011.307 (Tabaković et al. 2020).

\subsection{Reference system in the projection plane}

The correlation between the reference system in the projection plane BH_ETRS89/TM and the existing national coordinate system should be established by applying appropriate transformations based on a large number of observed points from all reference systems. That number has reached about 2,500 points by now, and through ongoing projects, the conditions for adequate transformation and establishment of a new reference system are expected to be created by the end of 2022.

\subsection{Vertical reference system}

Works on the establishment of the first high-accuracy leveling NVT I in the territory of Bosnia and Herzegovina were carried out in the period from 1945 to 1953 . This leveling is based on the vertical datum from 1875, and the elevations calculated in NVT I have been used until today (Krzyk, 2001).

More than 10 years after the works on NVT1, in 1967 a conclusion was adopted on the establishment of the second high-accuracy leveling NVT2. Activities on the establishment of the new leveling network lasted from 1970 to 1973, but unfortunately, the NVT2 data were never put into official use. Almost fifty years after these measurements, work has begun on the establishment of the third high-accuracy leveling NVT3 in the territory of the Federation of $\mathrm{BiH}$. The NVT3 network in the Federation of BiH consists of 2692 points, of which 1 normal benchmark in Maglaj, 33 fundamental benchmarks, 92 points of the spatial reference network, 972 vertical benchmarks and 1594 horizontal benchmarks. Of the 33 fundamental benchmarks, 15 were taken from NVT 2. Permanent marking of new (vertical and horizontal) benchmarks was performed on the basis of the designed leveling lines. Lower order benchmarks (precision, technical and higher-accuracy technical leveling benchmarks) located 
Ključanin, S., Redžepagić, E.

Introduction of the new geodetic datums and map projections in the Federation of Bosnia and Herzegovina

on the designed lines (Table 2) and which met the requirements set by the project, became an integral part of the new NVT3 network (Tabaković et al. 2020).

Table 2. Data on leveling lines (excerpt from the original table)

\begin{tabular}{|c|c|c|c|c|c|c|}
\hline $\begin{array}{l}\text { Leveling } \\
\text { line }\end{array}$ & $\begin{array}{l}\text { Leveling } \\
\text { line length } \\
(\mathrm{km})\end{array}$ & $\begin{array}{c}\text { Number of } \\
\text { benchmarks }\end{array}$ & $\begin{array}{c}\text { Fundamental } \\
\text { benchmark } \\
\text { number }\end{array}$ & $\begin{array}{l}\text { Number of } \\
\text { points of } \\
\text { spatial } \\
\text { reference } \\
\text { network }\end{array}$ & $\begin{array}{c}\text { Number of } \\
\text { vertical } \\
\text { benchmarks }\end{array}$ & $\begin{array}{c}\text { Number of } \\
\text { horizontal } \\
\text { benchmarks }\end{array}$ \\
\hline 1 & 59.4 & 61 & 0 & 3 & 32 & 26 \\
\hline 2 & 10.5 & 10 & 1 & 0 & 7 & 2 \\
\hline 3 & 22.4 & 27 & 0 & 1 & 2 & 24 \\
\hline 4 & 47 & 52 & 1 & 1 & 27 & 23 \\
\hline 8 & 55.2 & 59 & 1 & 2 & 22 & 34 \\
\hline 9 & 8.7 & 11 & 0 & 1 & 4 & 6 \\
\hline 30 & 54.7 & 66 & 1 & 2 & 19 & 44 \\
\hline 45 & 34.9 & 38 & 0 & 2 & 12 & 24 \\
\hline 46 & 37.4 & 41 & 1 & 3 & 16 & 21 \\
\hline 47 & 44.7 & 47 & 0 & 1 & 23 & 23 \\
\hline 48 & 20.3 & 23 & 0 & 1 & 12 & 10 \\
\hline 49 & 35.9 & 36 & 0 & 2 & 16 & 18 \\
\hline
\end{tabular}

In the period from August 2019 to October 2021, leveling measurements were performed on all planned leveling lines in the Federation of $\mathrm{BiH}$, and on lines connecting the two entities, as well as cross-border lines (Republic of Croatia) connecting the leveling network of the Federation of $\mathrm{BiH}$ with tide gauge in Dubrovnik A496 (15km leveling line from the FBiH border) and the datum point (benchmark) of the European high-accuracy leveling network in Plitvice HR008 (12km leveling line from the FBiH border).

\subsection{Gravimetric reference system}

The points of the absolute gravimetric network were measured in the period SeptemberOctober 2013. Absolute acceleration values were determined at four points using the absolute gravimeter Micro-g Lacoste FG5\# 233, while the vertical gradient was determined using the relative gravimeter Scintrex CG-5\# 740. Measurements were performed at four points in the territory of $\mathrm{BiH}$, and their coordinates with heights and the obtained absolute acceleration results are presented in Table 3 (Starčević, 2021).

Table 3. Position and height of absolute points and their acceleration values in the territory of $\mathrm{BiH}$ (Starčević, 2021)

\begin{tabular}{|l|l|l|c|c|}
\hline \multicolumn{1}{|c|}{ Point } & \multicolumn{1}{|c|}{ Latitude [WGS84] } & \multicolumn{1}{c|}{ Longitude [WGS84] } & Normal height [m] & $\begin{array}{c}\text { Absolute } \\
\text { accelerations [mgal] }\end{array}$ \\
\hline AG01 Banja Luka & $44^{\circ} 43^{\prime} 49.088^{\prime \prime}$ & $16^{\circ} 54^{\prime} 38.734^{\prime \prime}$ & 320.805 & 980515.045 \\
\hline AG02 Bijeljina & $44^{\circ} 36^{\prime} 50.802^{\prime \prime}$ & $19^{\circ} 06^{\prime} 22.477^{\prime \prime}$ & 202.509 & 980547.266 \\
\hline AG03 Sarajevo & $43^{\circ} 52^{\prime} 31.931^{\prime \prime}$ & $18^{\circ} 26^{\prime} 09.537^{\prime \prime}$ & 726.784 & 980319.770 \\
\hline AG04 Mostar & $43^{\circ} 20^{\prime} 54.015^{\prime \prime}$ & $17^{\circ} 47^{\prime} 36.295^{\prime \prime}$ & 96.277 & 980353.234 \\
\hline
\end{tabular}


Ključanin, S., Redžepagić, E.

Introduction of the new geodetic datums and map projections in the Federation of Bosnia and Herzegovina

The basic gravimetric network was measured in the period September-October 2014 in the entire territory of $\mathrm{BiH}$. The network consists of 60 third-order spatial reference network points (30 points in $\mathrm{FBiH}$ and 30 points in RS) located at a distance of 30 to 50 kilometers, which close a total of 45 polygons. This network was used as the basis for a detailed gravimetric survey of $\mathrm{BiH}$.

Based on measurements and calculations, the results of the standard deviation of gravity acceleration better than $0.016 \mathrm{mgal}$ were obtained. The points of absolute and basic gravimetric network will be used to support the measurements of gravity acceleration at the NVT3 benchmarks and for other gravimetric measurements.

The detailed gravimetric survey of benchmarks in the NVT3 network and the detailed gravimetric survey of $\mathrm{FBiH}$ were completed in 2017. Points of the detailed gravimetric survey were taken from several sources. Table 4 shows data on the name of the source of detailed points as well as records of the number of measured points.

Table 4. Names of point sources

\begin{tabular}{|c|c|c|}
\hline Description & Number of projected points & Number of measured points \\
\hline EUREF 98 & 8 & 13 \\
\hline BIHREF 2000 & 16 & 141 \\
\hline $\begin{array}{c}\text { Complementary Basic Gravimetric } \\
\text { Network points }\end{array}$ & 141 & 173 \\
\hline GRID points & 175 & 22 \\
\hline Control GRID points & 22 & 33 \\
\hline City GPS points & 33 & 1009 \\
\hline Detailed Gravimetric Network points & 1021 & 1398 \\
\hline Total number of points & 1416 & \\
\hline
\end{tabular}

The NVT3 network consists of a set of points that are permanently marked in leveling lines at distances from 300 to 1300 meters. It consists of the following points: 32 fundamental benchmarks, 77 points of spatial reference network, 883 vertical benchmarks and 1620 horizontal benchmarks (Figure 5). 
Ključanin, S., Redžepagić, E.

Introduction of the new geodetic datums and map projections in the Federation of Bosnia and Herzegovina

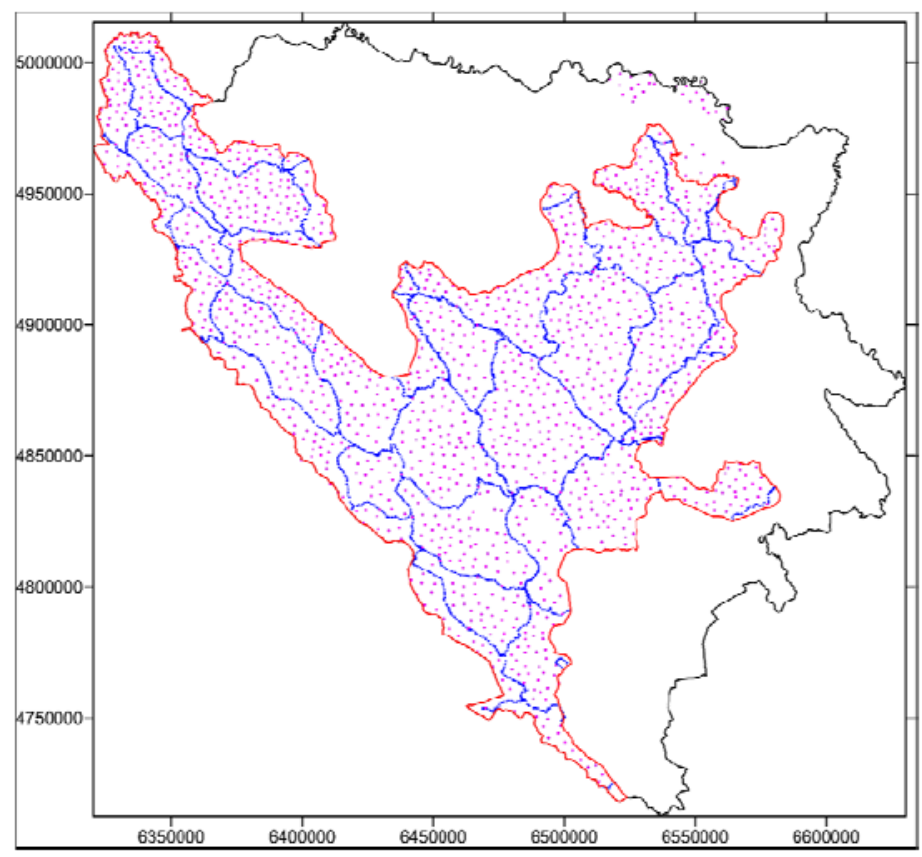

Figure 5. Measured points of detailed gravimetric survey (pink color) together with points of the leveling network (blue dots) (Starčević, 2021)

In order to confirm the quality of gravimetric measurements at the measured points, Bouguer's anomalies were calculated, on the basis of which the analysis of the present measurement or calculation errors was performed (Figure 6).

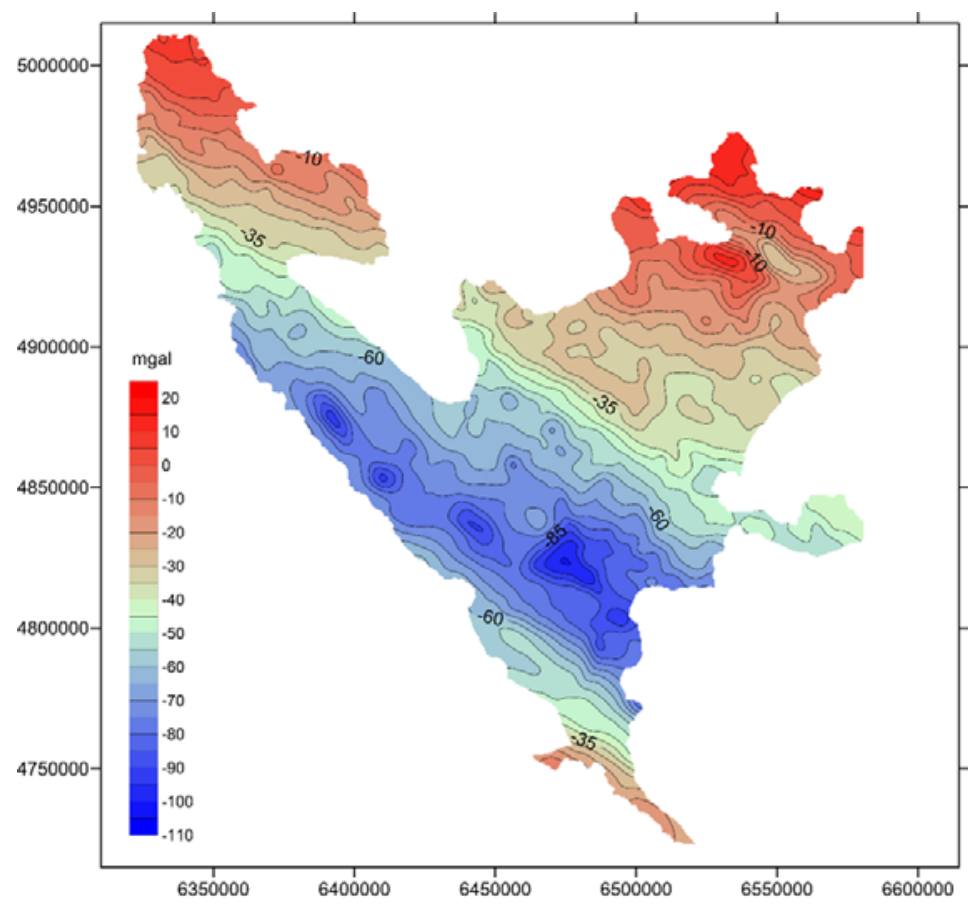

Figure 6. Map of Bouguer anomalies made on the basis of gravimetric measurements (Starčević, 2021) 
Ključanin, S., Redžepagić, E.

Introduction of the new geodetic datums and map projections in the Federation of Bosnia and Herzegovina

The mean errors of absolute accelerations at points are in the following ranges:

- $50 \%$ up to $100 \mu \mathrm{Gal}$

- $38 \%$ from 100 to $150 \mu \mathrm{Gal}$

- $11 \%$ from 150 to $200 \mu \mathrm{Gal}$

- $1 \%$ from 200 to $244 \mu \mathrm{Gal}$.

\section{CONCLUSION}

In the Federation of $\mathrm{BiH}$, new reference systems (new geodetic datums) have been established and their implementation in practice has begun. The Federal Administration for Geodetic and Property Affairs is making great efforts to provide adequate resources and other facilities necessary to perform activities in the field of basic geodetic works. In order to successfully move from the "old" to the "new" geodetic datums, it is necessary to continue the implementation of annual and three-year plans and thus systematically manage the implementation process.

From the realized works on the establishment of new reference systems, it can be concluded that the implementation of the new geodetic reference system is a very demanding, complex and time-consuming process and as such represents a great challenge. This is an opportunity for the entire geodetic (and cadastral) system of the Federation of $\mathrm{BiH}$ to prove itself and present a modern geodetic reference system that complies with modern international standards.

\section{REFERENCES}

1. Altiner, Y., Schlüter, W., Seeger, H. (1999): Results of the EUREF'98 GPS Campaigns in Albania, Bosnia and Herzegovina and Yugoslavia. Symposium of the IAG Subcommission for Europe, EUREF99, Prague, May 31 - June 6.

2. Bašić, T. (1999). Nužnost uvođenja novog geodetskog datuma u Rebublici Hrvatskoj i Bosni i Hercegovini (The necessity of introducing new geodetic datum in the Rebublic of Croatia and Bosnia and Herzegovina). First symposium of surveyors of Bosnia and Herzegovina "State and strategy of development of geodetic activity" At: Neum, 7-9 October 1999. Volume: Proceedings, 43-56, Mostar: https://www.researchgate.net/publication/277294467_Nuznost_uvodenja_novog_geodetskog _datuma_u_Rebublici_Hrvatskoj_i_Bosni_i_Hercegovini_The_necessity_of_introducing_new _geodetic_datum_in_the_Rebublic_of_Croatia_and_Bosnia_and_Herzegovina

3. Bašić, T., Bačić, Ž. (1999). Prijedlog geodetskog datuma Republike Hrvatske za treći milenij (Proposal for geodetic datum of the Republic of Croatia for the third millennium). Proceedings of the Symposium "State Geodetic Bases and Land Information Systems", pp. 117-128, Croatian Geodetic Society, Opatija 12-14 May

4. Bilajbegović, A., Mulić, M. (2013). Izbor optimalnog visinskog sustava na primjeru budućeg nivelmana Bosne i Hercegovine. Geodetski glasnik, year 47, No. 44, pp. 5-33.

5. Bilajbegović, A., Odalović, O. (2017). Detaljne tehničke specifikacije nivelmana visoke točnosti BiH. CILAP projekt i Federalna uprava za geodetske i imovinsko-pravne poslove.

6. Delčev, S., Timár, G., Kuhar, M. (2014): O nastanku koordinatnega sustava D48, Geodetski vestnik, 58, 4, 681-694.

7. Frančula, N., Lapaine, M. (2008). Geodetsko-geoinformatički rječnik. Državna gedoetska uprava, https://bib.irb.hr/datoteka/340862.rjecnik50_1.pdf 
Ključanin, S., Redžepagić, E.

Introduction of the new geodetic datums and map projections in the Federation of Bosnia and Herzegovina

8. Grgić, I., Lučić, M., Trifković, M. (2015). Visinski sustavi u nekim europskim zemljama. Geodetski list 2015, 2, 79-96.

9. Idhe, I. (2006). Global Vertical Reference System -Integration of Gravity and Geometric Reference. FIG Congress and INTERGEO 2006 Erdmessungsforum 12 October 2006 Munich

10. Krzyk, T. (2001). Nivelmanske mreže viših redova i vertikalni datum na području Bosne i Hercegovine. Geodetski glasnik, No. 35, year 35. Savez udruženja građana geodetske struke u Bosni i Hercegovini.

11. MGI (1901). Die Ergebnisse der Triangulierungen des K. und K. Militär-Geographischen Institutes in Wien, 1. Band.

12. Mugnier, C. (2012). Yugoslavia. https://www.asprs.org/wp-content/uploads/2012/05/0997-yugoslavia.pdf

13. Peterca, M., Čolović, G. (1987): Geodetska služba JNA, Vojnoizdavački i novinski centar, Beograd.

14. OG RS (2012): Rulebook for basic geodetic works, Official Gazette of the Republic of Serbia, No. 19/12, Belgrade.

15. Starčević, M, (2021). Final Report on gravimetric measurements in the Federation of Bosnia and Herzegovina. Working material. Federal Administration for Geodetic and Property Affairs.

16. Šugar, D., Zrinski, M., Rezo, M. (2015). Osnovni geodetski radovi prilikom uspostave pulskog bazisa i određivanja njegove duljine. Geodetski list, 2, 115-138. https://hrcak.srce.hr/142574

17. Tabaković, A., Redžepagić, E., Bojić, M. (2020). Aktivnosti na realizaciji mreže nivelmana visoke točnosti III u Federaciji Bosne i Hercegovine. Geodetski glasnik, No. 51, year 54. UDK 528. ISSN 1512-6102. Savez udruženja građana geodetske struke u Bosni i Hercegovini.

18. Vušović, N., Svrkota, I., Vaduvesković, Z. (2012). Spatial reference systems. Mining Engineering, No. 3, pp. 143-156. Mining and Metallurgy Institute Bor. Committee of Underground Exploitation of the Mineral Deposits. https://scindeksclanci.ceon.rs/data/pdf/1451-0162/2012/1451-01621203143V.pdf

19. Zimić, Š., Đonlagić, E. (2017). Uvođenje novih geodetskih referentnih sustava u Bosni i Hercegovini. Geodetski glasnik 51(48), 154-164.

20. URL1: https://www.fws.gov/r7/nwr/Realty/data/LandMappers/Public/Help/HTML/R7Public-Land-Mapper-Help.html?Datumsprojectionsandcoordinatesy.html

21. URL2: http://www.fgu.com.ba/bs/o-sustavu.html (accessed on 19.10.2021)

22. URL3: Kuhar, M. - Referenčni sustavi v geodeziji. Predavanja. http://fgg-web.fgg.unilj.si/ /mkuhar/Pouk/RSG/gradivo/5-Ref_sustavi-Transformacije.pdf (accessed on 19.10.2021)

23. URL4: http://fbihpos.katastar.ba/SBC/spider-business-center (accessed on 12.11.2021) 